\title{
Environmental education from an intercultural approach: A glimpse into Latin America
}

\author{
Helio Manuel García-Campos, Universidad Veracruzana, Mexico
}

\begin{abstract}
Latin America has established a new model of higher education termed intercultural, or indigenous, education. This essay analyses the potential that the integration of educational approaches focused on environmental sustainability and linked to intercultural education approaches could represent to Latin American institutions. The trend has set a new direction and opened up perspectives on integrating other fields, such as ethnoscience, agroecology, education and applied anthropology. Different aspects of the relationship between culture and nature are analysed, bearing in mind that biocultural diversity and its territorial expressions are part of a heritage that rural and indigenous societies present as a contribution to the current definition of civilizatory trends. Based on this review, the paper presents a comparative and integrative conceptual framework that can be used as a reference for practical applications of experience or as a search tool for educational alternatives that can bridge the gap between environmental and intercultural education.
\end{abstract}

Keywords: environmental education, intercultural education, intercultural universities.

It is interesting to note how, as problematisation fields, interculturality and sustainability view each other and establish a mutual dialogue within many intercultural higher education programme and policy proposals. Moreover, proposals based on the knowledge and traditions of indigenous or mestizo peoples - while avoiding the idealisation of these peoples - provides meaning and viability to alternative perspectives on sustainability and warns against discussions about 'universal sustainability' when culturally differentiated sustainability should be acknowledged instead. Hence the importance of addressing this perspective from an intercultural point of view.

In general, when scholars, teachers and students of the humanities and the social and natural sciences make frequent explorations or interventions into rural and indigenous worlds, they learn indigenous peoples' visions and strategies or make them visible, which then contributes to showcasing the contemporary viability of these world views and practices, and to highlighting new pedagogical possibilities.

The potential that this endeavour represents for Latin America is recognised by authors such as Ramos-García, Tenorio and Muñoz (2011), and Castaño-Cuellar, Pacheco and Bustos (2011), who pursue pedagogical proposals of education on natural science and environmental issues in intercultural contexts, as well as Castaño-Cuellar (2011), who focuses on the teaching of biology in bio-diverse and multicultural countries.

To begin with, we raise some pertinent questions. How, or in which way, can peoples and cultures with the lowest ecological footprint on the planet be taught sustainability? How can we learn from them in order to come to a new understanding of, and transform, societies that are based on the vision of progress and consumeristic, industrial urban development? 
Interculturality assumes the possibility of dialogue among the different visions coexisting within the framework of multicultural societies such as those of Latin American countries, and beyond that, the real possibility of enabling mestizo or highly 'westernised' sectors to acknowledge the relevance of native or Afro-American peoples' knowledge, and, vice versa, of enabling indigenous peoples' to integrate modern science into their knowledge systems. What would the form of a pedagogical perspective be that allowed for the coexistence and mutual enrichment of indigenous and rural knowledge and the knowledge of scientific culture? Discussing these matters leads to the identification of certain elements that inform a proposal for an intercultural environmental education for sustainability (IEES) approach in the current field of environmental education.

Mexico and Latin America are witnessing a dynamic process in which intercultural universities, also known as intercultural institutions of higher education (IIHEs), are being established (Mato, 2009). These institutions seek to counter the enfeeblement of those cultures and societies that have been endemically put at a disadvantage by the predominance of the western cultural model, which expresses itself at every level of society and education. Responses to this situation are included in current intercultural policies aimed at promoting and fortifying native cultures on the American continent.

A common element among Latin American IIHEs, and in fact among all Mexican intercultural universities, is the presence of formal, professional, academic programmes focused on various aspects of sustainability. Hence the interest in exploring the rationale and the theoretical, political and axiological elements that could underpin the fusion of interculturality and sustainability, especially as a result of the frequent postulation that indigenous or rural peoples, as well as peoples of African ancestry, possess epistemological and axiological knowledge that transcends the anthropocentric perspective of colonial European cultural heritage. Such a postulation is considered as having the potential to renew and re-define the discourse on sustainability and sustainable development.

Sustainability is not a universally acknowledged concept. In other words, it is not co-validated identically by every contemporary multicultural code. However, we propose the existence of certain equivalences between concepts rooted in traditional or indigenous knowledge systems and the definitions of sustainability developed from a scientific perspective over the past two decades. In fact, evidence for many of the concepts and strategies associated with sustainability has been easier to locate among indigenous and rural societies and communities. Hence the importance of these 'rural' societies:

which still today include around two billion people who belong to autochthonous rural or scarcely modern rural worlds, as well as 400 million people who belong to indigenous worlds [these worlds] are better prepared to endure the deep crisis scenarios that lie ahead of us, [because they are] the least modern and urbanized societies. As the global expansion of capitalism and its urban-agro-industrial system reach their frontiers. (Fernández-Durán, 2010:59-60)

The matter goes beyond Fernandez-Durán's conceptualisation here, and is not just related to natural resource management strategies only: it represents a more complex configuration 
that entails ontological, epistemological, ethical and political considerations that could have consequences for global civilisation.

This paper identifies some of the trends and elements that have led to the elaboration of proposals and policies that acknowledge IEES.

\section{From sustainability to interculturality in a globalised world}

The fields of sustainability and interculturality are relatively recent, and they respond to various expressions of the contemporary crisis - one of them from a socio-environmental perspective and the other from a cultural perspective. Although complementary ethical, epistemic and methodological relationships between both fields can be implicitly and practically assumed, there are few studies that seek to establish their existing or possible points of convergence with the intention of creating a highly pertinent transdisciplinary space in which to search for answers to the crisis.

Environmental education for sustainability (EES) and intercultural education (IE) are today essential parts of a promising line of enquiry. Because of their chronotopic condition (De Alba Ceballos, 2009), both conditions are bound to create and provide for theoretical and pragmatic approaches based on cultural and bio-ecological/environmental diversity aimed at constructing or re-formulating pertinent cultural, environmental and educational reflections, critiques, proposals and practices. In a similar vein, Leff, Argueta, Boege and Porto-Goncalves (2005:5) state that:

the globalisation process presents three fundamental challenges to sustainability: the conservation of biodiversity and the planet's ecological balances; democracy, social participation, and cultural diversity; knowledge, education, training, and information available to the citizenry.

Sustainability and interculturality should be combined so as to seek the answers required of a necessarily complex review. However, acknowledging the myriad perspectives on sustainability and interculturality calls for an inquiry into, and analysis of, the nature of the dialogue between these fields that takes into account their core ideas and epistemological, political and pedagogic principles.

'Sustainability' is a relatively recent concept, and, as such, it is not universally known or understood, even among the population that acts within the framework of contemporary western knowledge and culture itself. It is also probably not a concept that has been internalised by the citizen or within the general mental framework of western human consciousness. Likewise, it is unlikely an equivalent connotation could be found among indigenous cultures, particularly among the Mesoamerican, ${ }^{1}$ Andean or Amazonian cultures of Latin America. This lacuna also occurs with the other term commonly associated with sustainability, namely, 'development'.Viteri-Gualinga (2002:2) writes that this is due to:

the lack of a linear life process that establishes what development or underdevelopment are or their previous or future states, a dichotomy people must go through in order to achieve a 
desirable life, as it is in the western world. There are also no concepts of wealth or poverty determined by the accumulation or lack of material goods.

This fact, however, should not impede the search for possible 'equivalences' that indigenous cultures might possess with regards to the concepts of 'development' and 'sustainability' such as, for example, the corresponding Andean-Amazonian concept of súmak káusai. There is now a growing number of references to recent processes and initiatives in which South American nations, such as Ecuador and Bolivia, have included this concept in their national constitutions. In 2009, in a process termed the 'biocentric turn' by Eduardo Gudynas (2009), the circumstances were ripe for this change because of the administrations of progressive presidents in both countries, and, in the case of Bolivia, the first indigenous president.

Súmak káusai is usually defined as 'living well' or 'harmonious life' (Gudynas, 2009; Mato, 2008; Viteri-Gualinga, 2002; among others), or 'living well, being well' (Vargas-Callejas, 2005), with the proviso that this type of living must be based on respect for the Pachamama (Mother Earth) in correspondence with the well-known idea shared by indigenous cultures that humankind is part of nature.

More recently, in the Mexican state of Chiapas some academic and social actors have also begun to incorporate this 'living well' concept (lekil kujlejal), based on a common matrix of principles shared by peoples such as the Tojolabal, Tzotzil, Tzetzal, Ch'ol and Zoque (Sartorello, Ávila \& Ávila, 2012).

Based on studies by anthropologists and ethnoecologists, Leff et al. (2005:21) state that:

many ecological and cultural conditions of sustainability have been incorporated into production practices of 'traditional' societies and are reflected in both their symbolic formations and their technological tools, which have been configured after long processes of coevolution with nature, environmental transformation, and cultural assimilation. Production practices based on cultural symbols inspired by the environment, religious beliefs, and social meanings assigned to nature have resulted in different forms of perception and appropriation, social rules for access and usage, ecosystem management practices, and production and resource consumption patterns. This is how traditional agricultural ideologies and productive strategies were configured in Mesoamerica.

Supported by the struggles of indigenous peoples, their organisations and their representatives throughout the world, this is a long process, one in which different national and international pieces of legislation have gained legitimacy by being informed by a legal pluralism emanating from cultural diversity. There are common underlying elements and visions that lead to the recognition of indigenous knowledge and the rights of native peoples to take ownership of nature because they are part of a strategy to counter the hoarding and plundering of resources and biodiversity taking place in their territories, and who are frequently threatened by governments and private corporations driven by the neoliberal vision of unlimited economic growth.

It is because of the wealth of knowledge, visions and ethics held by native peoples contributing to the construction of contemporary responses to planetary and civilising dilemmas that such 
knowledge must be advanced because of their potential to renew educational discourse and initiatives. However, it is necessary to transcend the clichéd and romanticised depiction of the efforts to redeem indigenous cultural values, since these values themselves are vulnerable to deterioration and transformation in the hands of modernisation and globalisation.

\section{Interculturality addresses sustainability}

In the same way that EES has failed to embed perspectives of cultural diversity in its curricula, intercultural studies and intercultural education have also failed to integrate environmentrelated themes and socio-environmental sustainability considerations into their programmes.

At first, it would seem that intercultural studies, including intercultural education, fail to consider sustainability as forming part of the 'diverse academic currents which signal deep transformations in the objectives of the social sciences' (Dietz, 2003). This is probably because sustainability - an interdisciplinary field that has not yet been incorporated into social science as comprehensively as other, already-established fields - is seen as being more directly related to environmental and technical disciplines. This view overlooks the fact that, compared with its ecological component, sustainability does a better job of incorporating the social, political, and cultural dimensions necessary for a holistic approach.

If we consider that intercultural studies are the result of multiculturalist movements that have gradually embraced the discourse of interculturality as part of the current evolution of the discussion, they must be considered an important part of anti-globalisation social movements that challenge what De Sousa Santos (2007) calls abysmal thinking. This is a mindset that separates the western tradition from non-western world views and leads to global cognitive injustice. For that reason, such movements - their thinkers and their leaders - advocate new forms of utopianism and view the promotion of social, ethnic and epistemological equity as a constituent part of the interculturality-sustainability dyad. Even if the terms sustainability and interculturality are never used by many indigenous intellectuals and leaders (or even by scholars who study these matters), there are certainly other expressions more or less equivalent to such a terms, and thus, as previously stated, it becomes relevant to explore the new paradigm of what is known as súmak káusai.

Such an equivalence would be difficult to translate inter-linguistically because of various epistemological constructs differentiated by culture. In view of the lack, or even the nonexistence, of conceptual and idiomatic translocation of concepts such as interculturality and sustainability among indigenous cultures, an intuitively adequate way to establish a point of reference that bridges and allows for intercultural dialogue begins by identifying the particular visions that these cultures have, as well as their cognitive outlook, ethics and practical approach to the relationships between society, culture and nature. In this regard, ethnosciences, their principles and their methods are currently providing some of the best possible ways to reveal paths and resources that could establish a dialogical exchange of knowledge, both academic and otherwise (diálogo de saberes, Leff, 2004) around the interculturality-sustainability agenda.

Despite that fact that these 'local models of the natural world form the base of today's environmental struggles' (Escobar, 2003:78) and that they also form the base of what are 
considered social ethnoecological movements, a direct original response to the 'Eurocentric world' and the dominance of 'modern instrumental rationality', these last two ideas still represent a strong opposition to them and deny the evidence that 'this vision spells doom to a regime that intertwines biology and history, supported by the capitalisation of nature and work' (Escobar, 2005:88).

\section{Toward a comparative synthetic perspective}

With the intention of exploring some of their characteristics, the following table summarises a proposal that allows for a possible comparative vision, and eventually a synthesised vision of the components of an IEES. The main purpose of this exercise was to establish a basic conceptual key for exploration when integrative projects are applied to sustainability and interculturality. Certainly, economic, technological or spiritual dimensions, among others, could also have a place in this matrix, and could be analysed in the same comparative and complementary sense.

Table 1. Complementary characteristics of environmental education for sustainability (EES) and intercultural education (IE), with a view to establishing a synthesis for intercultural environmental education for sustainability (IEES)

\begin{tabular}{|c|c|c|}
\hline & $\begin{array}{l}\text { Environmental education for } \\
\text { sustainability (EES) }\end{array}$ & Intercultural education (IE) \\
\hline Ethics & $\begin{array}{l}\text { - Interdependence between } \\
\text { nature and society. } \\
\text { - Transgenerational responsibility } \\
\text { toward the satisfaction of future } \\
\text { human needs. } \\
\text { - Some indigenous visions } \\
\text { attribute rights to nature as well } \\
\text { as to human beings. }\end{array}$ & $\begin{array}{l}\text { - Recognises multiculturalism as a fact. } \\
\text { - Promotes the need to accept others } \\
\text { who are culturally, generationally, or } \\
\text { generically different. } \\
\text { Recognises the need to be } \\
\text { empathetic and be able to adopt } \\
\text { diverse identities in order to } \\
\text { understand the 'other's' conditions. }\end{array}$ \\
\hline Globalisation & $\begin{array}{l}\text { - Considers generalised } \\
\text { phenomena that result in } \\
\text { environmental degradation } \\
\text { (climate change, loss of } \\
\text { biodiversity, etc.) and affect } \\
\text { environmental processes and } \\
\text { local ecosystems. }\end{array}$ & $\begin{array}{l}\text { - Acknowledges the phenomenon and } \\
\text { processes of exchange flow between } \\
\text { human populations from different } \\
\text { countries and cultures. } \\
\text { - Addresses problems associated with } \\
\text { the coexistence between different } \\
\text { ethnic or social groups and promotes } \\
\text { tolerance and dialogue. }\end{array}$ \\
\hline $\begin{array}{l}\text { Location } \\
\text { (Note: Use of the term } \\
\text { 'geolocation' is an } \\
\text { attempt to resolve these } \\
\text { two issues.) }\end{array}$ & $\begin{array}{l}\text { - States that the management } \\
\text { of environmental issues and } \\
\text { local resources can be better } \\
\text { accomplished by using a local } \\
\text { or bio-regional perspective } \\
\text { and potentiating the specific } \\
\text { characteristics of each context } \\
\text { in educational terms. }\end{array}$ & $\begin{array}{l}\text { - Identifies and encourages responses } \\
\text { that seek an affirmation of local } \\
\text { identities as a basic and pertinent } \\
\text { solution to the erosion of local } \\
\text { culture in the face of globalisation. }\end{array}$ \\
\hline
\end{tabular}




\begin{tabular}{|c|c|c|}
\hline & $\begin{array}{l}\text { Environmental education for } \\
\text { sustainability (EES) }\end{array}$ & Intercultural education (IE) \\
\hline Diversity & $\begin{array}{l}\text { - Bio-ecological diversity is the } \\
\text { result of temporal processes } \\
\text { and pulses of nature at different } \\
\text { scales. } \\
\text { - This baseline represents the } \\
\text { best opportunity to preserve } \\
\text { the functioning of ecosystems } \\
\text { by virtue of the richness of } \\
\text { possible responses to ecosystem } \\
\text { disruptions. }\end{array}$ & $\begin{array}{l}\text { - Refers to cultural diversity. } \\
\text { - Involves the recognition and } \\
\text { strengthening of local cultures, not } \\
\text { only from the ethnic point of view. } \\
\text { - Is the most important resource } \\
\text { in potentiating political and } \\
\text { organisational responses. } \\
\text { - Cultural diversity provides better } \\
\text { response opportunities to the } \\
\text { imposition of monocultural processes } \\
\text { advocated by the hegemonic } \\
\text { globalising discourse. }\end{array}$ \\
\hline Knowledge & $\begin{array}{l}\text { - Utilises an interdisciplinary } \\
\text { repertoire as the most } \\
\text { appropriate response } \\
\text { to the complexity and } \\
\text { multidimensionality of factors } \\
\text { involved and the conditions for } \\
\text { coexistence between society } \\
\text { and nature. }\end{array}$ & $\begin{array}{l}\text { - Emphasises and favours the value of } \\
\text { local knowledge and creativity but } \\
\text { considers the existence of exogenous } \\
\text { knowledge. } \\
\text { - An 'ecology of knowledge' in } \\
\text { interaction that thrives under a } \\
\text { dialogue maintained in conditions of } \\
\text { epistemological equity. }\end{array}$ \\
\hline Culture & $\begin{array}{l}\text { - Considers that the } \\
\text { environment, ecosystems, and } \\
\text { biological species are frequently } \\
\text { products of co-evolution } \\
\text { between culture and nature. } \\
\text { - A major resource to preserve } \\
\text { biocultural heritage associated } \\
\text { with indigenous regions, } \\
\text { biological conservation, and the } \\
\text { strengthening of cultures. }\end{array}$ & $\begin{array}{l}\text { By recognising multicultural reality, } \\
\text { promotes dialogue and mutual } \\
\text { respect between members of } \\
\text { different cultures. } \\
\text { - Puts forward the recognition and } \\
\text { strengthening of local and indigenous } \\
\text { cultures before the influence and } \\
\text { imposed threat of monocultural } \\
\text { processes driven by globalisation and } \\
\text { resulting in cognitive injustice. }\end{array}$ \\
\hline $\begin{array}{l}\text { Nature } \\
\text { (Note: In Mexico, there } \\
\text { is an ongoing discussion } \\
\text { about the biocultural } \\
\text { heritage or biocultural } \\
\text { memory of indigenous } \\
\text { peoples, a proposal } \\
\text { based on recognising } \\
\text { the complexity of the } \\
\text { relationships among } \\
\text { society, culture and } \\
\text { nature.) }\end{array}$ & $\begin{array}{l}\text { - A matrix for the survival } \\
\text { of all species, civilisations, } \\
\text { and cultures into which } \\
\text { individuals, communities, and } \\
\text { societies metabolise their basic } \\
\text { biophysical relationships as they } \\
\text { 'environmentally exists'. }\end{array}$ & $\begin{array}{l}\text { - Recognises its role in cultural } \\
\text { inspiration and creation (mirror and } \\
\text { identity of peoples). } \\
\text { - In many Latin American countries, } \\
\text { the current trend recognises nature's } \\
\text { rights (Mother Earth, Pachamama) } \\
\text { even at the constitutional level. }\end{array}$ \\
\hline
\end{tabular}




\begin{tabular}{|c|c|c|}
\hline & $\begin{array}{l}\text { Environmental education for } \\
\text { sustainability (EES) }\end{array}$ & Intercultural education (IE) \\
\hline $\begin{array}{l}\text { Policy/ } \\
\text { organisation/ } \\
\text { regulations }\end{array}$ & $\begin{array}{l}\text { - Promotes the values of } \\
\text { democracy and citizenry } \\
\text { participation and education } \\
\text { in the reappraisal of nature } \\
\text { as commons as opposed to the } \\
\text { hoarding and monopolisation } \\
\text { of natural resources. } \\
\text { - Sympathetic toward the } \\
\text { emancipation of minorities } \\
\text { from the negative consequences } \\
\text { they suffer (environmental justice). }\end{array}$ & $\begin{array}{l}\text { - Recognises and promotes the value } \\
\text { of local institutions and the legal } \\
\text { plurality of indigenous peoples who } \\
\text { coexist with 'national societies'. } \\
\text { - Seeking social equity for indigenous } \\
\text { peoples and minorities within } \\
\text { multicultural nations is a priority. }\end{array}$ \\
\hline Sustainability & $\begin{array}{l}\text { - A complex, multidimensional } \\
\text { vision. } \\
\text { - Goes beyond the frequent } \\
\text { equivalence of sustainability = } \\
\text { environment conservation and } \\
\text { improvement. } \\
\text { - Favours the 'strong' or 'super } \\
\text { strong' current that criticises } \\
\text { and challenges the system } \\
\text { (establishment). }\end{array}$ & $\begin{array}{l}\text { - Not every culture, especially the } \\
\text { indigenous cultures, possesses an } \\
\text { equivalent concept. } \\
\text { - While a polysemic concept, even } \\
\text { in western cultures, it seeks the } \\
\text { recognition of correspondences or } \\
\text { indicators of indigenous cultural } \\
\text { values similar to some notions of } \\
\text { sustainability. }\end{array}$ \\
\hline Educational streams & $\begin{array}{l}\text { Ethnographic environmental } \\
\text { education; popular environmental } \\
\text { education; multicultural } \\
\text { environmental education; } \\
\text { eco-pedagogy. }\end{array}$ & $\begin{array}{l}\text { Multicultural education; indigenous } \\
\text { education; citizen education; } \\
\text { intercultural pedagogy. }\end{array}$ \\
\hline
\end{tabular}

\section{Conclusions}

A promising approach to strengthen the relationship between environmental education for sustainability and intercultural education focuses on the 'culturalisation' of environmental education, thus creating standpoints from which to reflect on the differences between cultures and directing relevant efforts toward the construction of complex concepts such as sustainability (a term that has not been universally understood from the postulates of scientific and western discourses). This is done by incorporating the practices and visions of traditional societies, which are based on ecological and cultural conditions of co-evolution between society and nature, and which have been acknowledged and made part of the deontologic code of sustainability.

Intercultural education, particularly in Latin America, makes a priority of addressing the concerns of indigenous and Afro-American populations. However, the construction of innovative paths - originating in intercultural sources of knowledge and the intercultural discourse itself - should also attempt to broaden the concept of those 'others' who should be included in the discussion toward a biocentric dimension. As Eduardo Gudynas (2009) would put it, the 'others' include all the other species sharing the Earth with humankind. 
Specific possibilities of application in this sense are visualised, for example, through the promotion and exchange of knowledge between actors of cultures, peasants, indigenous people and those professionals or university students from the mestizo cultures, through productive projects (agriculture, forestry, livestock and domestic plots) that would aim to achieve the careful extraction and use of nature's resources. Overcoming the hierarchies among experts and advisors would promote co-learning. The technicians would participate in the development of their own production and conservation strategies, learning to build a relationship that is different to the typical one of simple technology transfer.

Furthermore, in the field of health, there already exist important examples where differentiated medical systems are contrasted - such as the traditional indigenous types (herbalism, midwifery) and the modern allopathic model giving rise to the desired dialogical exchange of knowledge-wisdom (diálogo de saberes as per Leff, 2004), which is proposed as worthy goal in the processes of intercultural dialogue.

The growing presence of intercultural universities, most of them located in predominantly rural and indigenous territories, creates favourable conditions for promoting the development of an environmental education for sustainability arising from a rural context in 'situated' or 'localised' educational or intervention modes that take into account the specific environmental and cultural contexts of those territories. Such predominantly rural regions are not exempt from the negative effects of the urban-industrial/agro-industrial model of civilisation, but it is with regards these environments where the possible future direction of civilisation needs to be discussed.

Even though IEES proposals are currently directed at indigenous peoples, the focus should be redirected towards the questions of why and how native peoples' traditional knowledge and cultural heritage are pertinent with respect to re-creating contemporary culture and civilisation on the entire planet. It is essential to know how the 'ecology of differences' can flow in both directions, toward the different social and cultural groups of particular locations, regions, nations and continents and toward the planet as a whole. The central question is how influences can be made mutual by promoting an 'ecology of knowledge-wisdom' (De Sousa Santos, 2007) to bring about constant, commonplace and creative dialogue.

\section{Endnote}

1. Mesoamerica is a historical region and cultural area in North America. It extends from central Mexico through Belize, Guatemala, El Salvador, Honduras, Nicaragua, and northern Costa Rica, and within this region pre-Columbian societies flourished before the Spanish colonization of the Americas. In the 16th century, European diseases like smallpox and measles caused the deaths of upwards of $90 \%$ of the indigenous people. It is one of five areas in the world where ancient civilization arose independently, and the second in the Americas along with Norte Chico (Caral-Supe) in present-day Peru, in the northern coastal region. (Retrieved from: https://en.wikipedia.org/wiki/Mesoamerica [accessed 27 May 2019]) 


\section{Notes on the contributor}

\section{García-Campos, Helio Manuel}

Center for Ecoliteracy and the Dialogue of Knowledges, Universidad Veracruzana, Mexico

ORCID: 0000-0002-3256-9707 | helgarcia@uv.mx; gc.helio@gmail.com

A biologist by training, Professor García-Campos has worked in the field of environmental education related to grassroots organisations in protected natural areas and environmental social movements. He lectures on intercultural and biocultural heritage issues.

\section{References}

Castaño-Cuellar, N.C. (2011). Enseñanza de la biología en un país biodiverso, pluriétnico y multicultural. Aproximaciones epistemológicas. Bio-grafías, (Número Extraordinario), 560-586.

Castaño-Cuellar N.C., Pacheco, D. \& Bustos, E. (2011). Aproximación a las prácticas educativas en tres contextos culturalmente diversos desde la perspectiva de los estudiantes en formación de la Licenciatura en Biología. Bio-grafías, 4(7), 94-107.

De Alba Ceballos, A. (2009). Educación ambiental para la sustentabilidad. Las posibilidades del contacto cultural. Memoria electrónica del X Congreso Nacional de Investigación Educativa, Veracruz.

De Sousa Santos, B. (2007). Para além do Pensamento Abissal: Das linhas globais a uma ecologia de saberes. Revista Crítica de Ciências Sociais, 78, 3-46.

Dietz, G. (2003). Multiculturalismo, interculturalidad y educación: Una aproximación antropológica. Granada y México: EUG \& Ciesas.

Escobar, A. (2003). Mundos y conocimientos de otro modo. El programa de investigación de modernidad/colonialidad latinoamericao. Tabula Rasa, 1, 58-86.

Escobar, A. (2005). Más allá del Tercer Mundo. Globalización y diferencia. Bogotá: Instituto Colombiano de Antopología e Historia.

Fernández-Durán, R. (2010). El antropoceno: La crisis ecológica se hace mundial. La expansión del capitalismo global choca con la Biosfera. Madrid:Virus.

Gudynas, E. (2009). La ecología política del giro biocéntrico en la nueva Constitución de Ecuador. Revista de Estudios Sociales 32, 34-47.

Leff, E. (2004). Racionalidad ambiental y diálogo de saberes. Polis: Revista Latinoamericana, 7. Retrieved from: http://polis.revues.org/6232.

Leff, E., Argueta, A., Boege, E., \& Porto-Goncalves, C.W. (2005). Más allá del desarrollo sostenible: Una visión desde América Latina. Revista Futuros, 3(9). Retrieved from: http:// www.revistafuturos.info [accessed 2 October 2008].

Mato, D. (2008). Diversidad cultural e interculturalidad en educación superior. Experiencias en América Latina. Caracas: IESALC-UNESCO.

Mato, D. (2009). Instituciones interculturales de educación superior en América Latina. Procesos de construcción, logros, innovaciones y desafíos. Caracas: IESALC-UNESCO. 
Ramos-García, C., Tenorio, A.D. \& Muñoz, F. (2011). Tejiendo cosmologías: Educación ambiental en contextos interculturales, el caso del clima, y los ciclos naturales ligados al sol y a la luna. Bio-grafías, (Número Extraordinario), 168-177.

Sartorello, S.F., Ávila, L.E., \& Ávila, A. (Eds) (2012). El buen vivir: miradas desde adentro de Chiapas. México: UNICH-IESALC-UNESCO.

Vargas-Callejas, G. (2005). Educación y desarrollo en Los Andes. Frankfurt: Peter Lang Europäischer Verlag der Wissenschaften.

Viteri-Gualinga, C. (2002).Visión indígena del desarrollo en la Amazonía. Polis: Revista de la Universidad Bolivariana, 3, 2-7. 